\title{
Rjava lipovka [Oxycarenus lavaterae (Fabricius, 1787)] je v Sloveniji vse pogostejša
}

\section{Maja JURC*}

Rjavo lipovko uvrščamo v družino gozdnih tekačev ali vitezovk (druž. Lygaeidae) in red stenic (Heteroptera). Vrsta je toploljubna, njena prvotna razširjenost je Mediteran, od jugozahodne Afrike, Savdske Arabije, Jemna, do Portugalske in južne Francije ter v tropskem in južnem delu Afrike. Postala je invazivna vrsta, ki se v zadnjih desetih letih širi na sever, v območja, ki postajajo toplejša. Gradacijo rjave lipovke so zabeležili leta 1994/1996 v severni Španiji v urbanem okolju, leta 1999 so jo našli na Slovaškem, v Avstriji so jo prvič opazili leta 2001, leta 2004 v Nemčiji, v jesenskem in zimskem obdobju 2004/2005 so zabeležili namnožitev rjave lipovka v Baslu v severni Švici. Za Madžarsko obstaja podatek o najdbi iz leta 1994, na Hrvaškem je stalno prisotna (objavljeno leta 2003). Podatki o tej vrsti v Sloveniji se kar vrstijo: najstarejši dokumentirani podatek o najdbi stenice je iz leta 1886 v bližini Gorice. Glede na podatke iz 19. stoletja nekateri raziskovalci menijo, da je vse ozemlje južno od Alp del prvotnega areala te vrste (Rabitsch, 2008). V novejšem času dokumentirane najdbe rjave lipovke so iz let 1987, 1992, 1995, 2000, 2003 in 2004, na obali, v Novi Gorici, Ljubljani, na Ljubljanskem barju pri Logu in $\mathrm{v}$ Prekmurju (Murska Sobota). Iz let 2001, 2007 in 2008 so podatki iz različnih delov Ljubljane in iz Pomurja. Gozdarji so O. lavaterae zabeležili večkrat: leta 2001 se je množično pojavila v Brežicah in okolici, leta 2002 v GE Novo mesto, leta 2004 množičen pojav v GE Nazarje, leta 2004 in 2005 v Grobljah pri Stahovici. Leta 2007 in 2008 je bila pogosto opažena v Ljubljani (Pot spomina in tovarištva, osnovna šola Dravlje in druge lokacije) ter v Domžalah. Septembra 2011 pa je zabeležen sporadični pojav O. lavaterae na Rožniku v Ljubljani. V poročilu o invazivnih tujerodnih vrstah v Evropi je O. lavaterae označena kot invazivna ustaljena tujerodna vrsta za Slovenijo (DAISIE, 2011).

O. lavaterae je rastlinojeda stenica in sesa sokove iz tanjše skorje poganjkov in iz listov različnih vrst lip (druž. Tiliaceae) in slezenovk (druž. Malvaceae). Zaradi najpogostejše gostiteljske rastline (lipe) in značilne barve ima stenica slovensko ime rjava lipovka. Populacija O. lavaterae je v Sloveniji ustaljena, število najdb narašča.

Žuželka je velika od 4 do 6 mm, ima ozko oprsje s temnim trikotnikom ter značilna krila, ki so tako kot pri vseh stenicah v prvi tretjini hitinizirana, barva kril prehaja iz rdečkaste $\mathrm{v}$ sivo srebrno (slika 1). Zbirajo se v večjih kolonijah, ki so sestavljene večinoma iz ličink ali iz odraslih stenic (slika 2). Ličinke zadnjih stadijev imajo rdečkast zadek in nepopolno razvita krila. Rdečkasti zadki stenic dajejo celotnim kolonijam rdečkasto barvo, konice kril odraslih stenic se srebrnkasto svetijo na soncu. V toplejših predelih Evrope razvije tri do štiri generacije letno, življenjski krog zaključi v 30-40 dneh. Sesa v krošnjah na tanjših poganjkih (slika 3).

O vplivu rjave lipovke na gostiteljske rastline je malo literaturnih podatkov, vendar o poškodbah ne poročajo. Pri nas zasledimo le zapis, da rjava lipovka povzroča deformacije in natrganine zaradi vbodov sesala na listih lipovca (Tilia cordata Mill.) v primorskem območju. V primeru ponavljajočih se, masovnih napadov sesanje stenic lahko povzroča izčrpavanje in hiranje gostiteljske rastline. Pri opazovanju izredno množičnega pojava rjave lipovke v urbanem območju Domžal leta 2008 smo opazili iznakaženo listje in sušenje lipovih poganjkov (slika 4).

Poskuse zatiranja rjave lipovke s piretroidi in organofosfati so izvajali v tujini, vendar zatiranja s kemičnimi sredstvi ne priporočajo, še posebej zato ne, ker se množično pojavlja predvsem v urbanem okolju. Moteče kolonije stenic, ki lahko obsegajo nekaj $\mathrm{dm}^{2}$ velike površine na deblih in vejah, lahko odstranimo mehansko (z močnim curkom vode ali enostavno s pometanjem rojev iz skorje). Gruče stenic na tleh uničimo tako, da jih zmečkamo. V novejših raziskavah uporabljajo določene snovi (ribosomske proteine, spermalne proteine idr.), ki vplivajo na razvoj jajčec v ovarijih samic, s katerimi skušajo najti učinkovite načine zmanjšanja gostote populacij $O$. lavaterae v urbanem okolju.

\section{Viri}

Delivering Alien Invasive Species Inventories for Europe (DAISIE), http://www.europe-aliens.org/regionSearch.do, 20.12. 2011

Gogala A., Gogala M. 1989. True Bugs of Slovenia (Insecta: Heteroptera). Biol. vestn., 37:11-44.

Gogala A. 2007. Heteroptera of Slovenia, IV: Pentatomomorpha I. Annales, Ser. hist. nat., 17, 1:61-92.

Jurc D. 2005. Stenice na lipah v Grobljah. Gozdarski inštitut Slovenije, Ljubljana, 1. str. (tipkopis)

Matošević D. 2003. Štetna entomofauna drvenastih biljnih vrsta urbanog zelenila grada Zagreba. Magistrsko delo, $161 \mathrm{str}$.

Polajnar J., Trilar T. 2009. Novi podatki o pojavljanju rjave lipovke (Oxycarenus lavaterae) (Heteroptera: Lygaeidae) v Sloveniji. Nat. Slov., 11,1: 69-70.

Rabitsch W. 2008. Alien True Bugs of Europe (Insecta: Hemiptera: Heteroptera). Zootaxa, 1827:1-44.

Rener I. 2003. Množično pojavljanje stenice Oxycarenus lavaterae F. na deblih lipovca (Tilia cordata) : [O.E. Novo mesto]. Ljubljana: Gozdarski inštitut Slovenije, Poročevalska, diagnostična in prognostična služba za varstvo gozdov, 3 str.

Rener I. 2004. Množično pojavljanje stenice Oxycarenus lavaterae F. na deblih lipovca (Tilia cordata) : [O.E. Nazarje]. Ljubljana: Gozdarski inštitut Slovenije, Poročevalska, diagnostična in prognostična služba za varstvo gozdov, 3 str.

1Univerza v Ljubljani, Biotehniška fakulteta, Oddelek za gozdarstvo in obnovljive gozdne vire, Večna pot 83, 1000 Ljubljana *maja.jurc@bf.uni-lj.si 


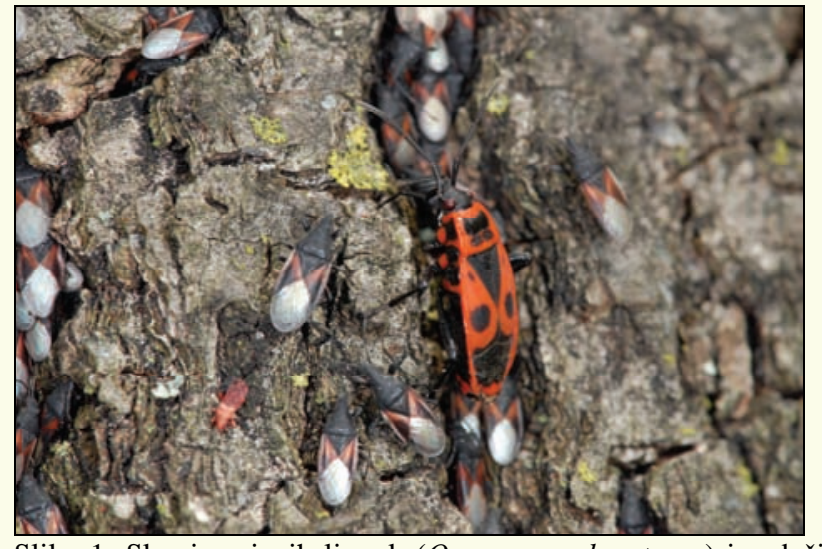

Slika 1: Skupina rjavih lipovk (Oxycarenus lavaterae) in rdeči škratec (Pyrrhocoris apterus), 3.5.2008, Domžale (foto: D. Jurc)

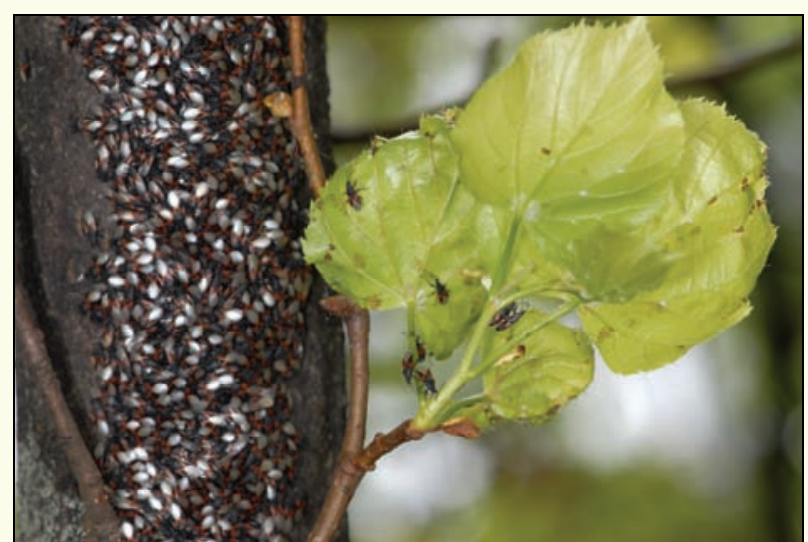

Slika 3: Rjave lipovke se pogosteje pojavijo na delih skorje, kjer sesajo sokove iz tanjše skorje poganjkov in iz listov različnih vrst lip, 3.5.2008, Domžale (foto: D. Jurc)

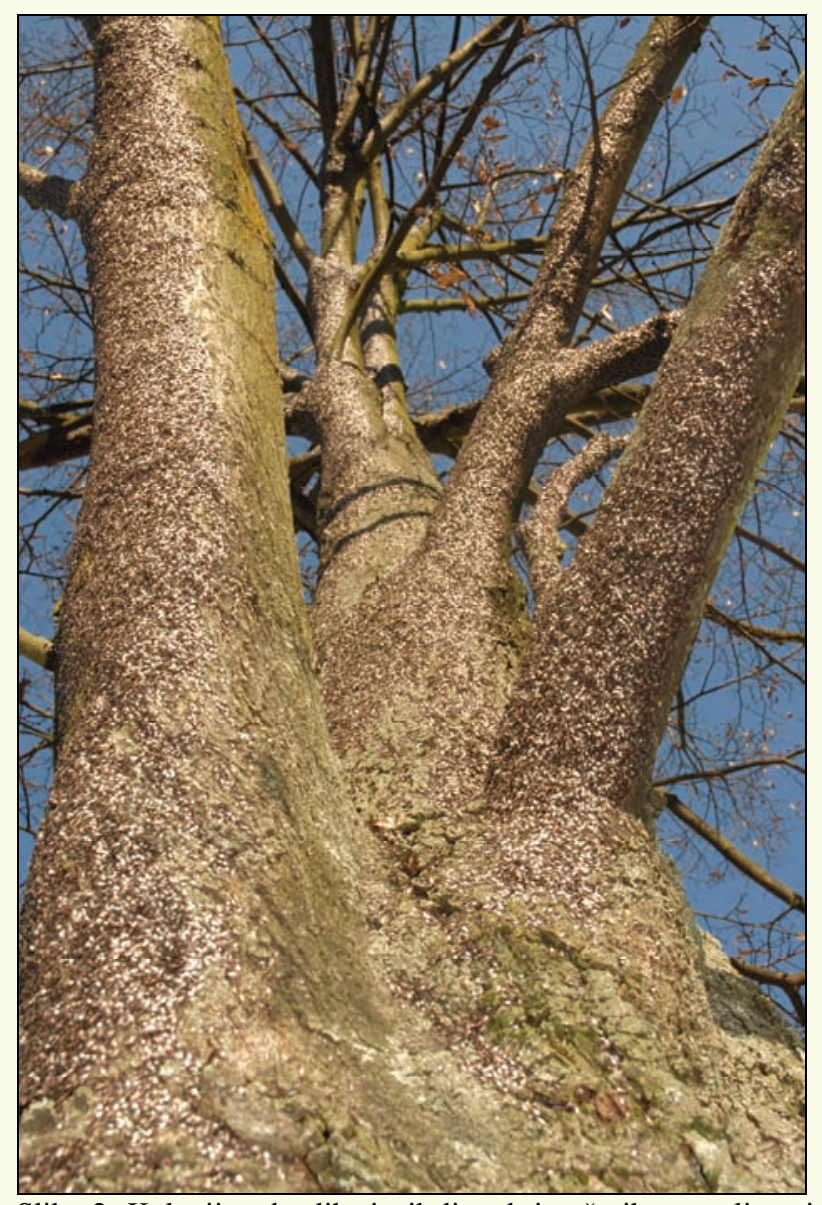

Slika 2: Kolonija odraslih rjavih lipovk je včasih sestavljena iz večplastnih in do $1 \mathrm{~m}^{2}$ velikih krp, 8.2.2008, Ljubljana (foto: M. Jurc)

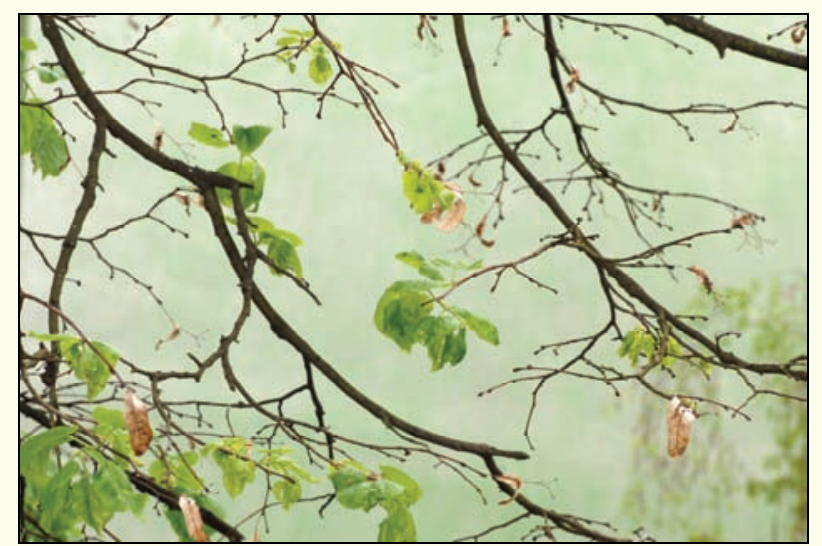

Slika 4: Pri izredno množičnem pojava rjave lipovke v urbanem območju Domžal leta 2008 smo opazili iznakaženo listje in sušenje lipovih poganjkov (foto: M. Jurc) 